\title{
A RECONCILIATION WITH DARWIN? ERICH WASMANN AND JAIME PUJIULA'S DIVERGENT VIEWS ON EVOLUTIONISM: BIOLOGISTS AND JESUITS
}

\author{
Juli Peretó AND Jesús I. CATAlÀ
}

Unlike the case of Galileo, the Catholic Church has managed evolutionism and Charles Darwin's work with discretion. Among Catholic scientists, some defend a variety of evolutionism which is peppered with remarkable exceptions, such as the divine origin of life and of the human species. The Jesuit entomologist Erich Wasmann came to the conclusion that the evolutionary theory could explain his observations about myrmecophiles, so he adopted a Catholicism-tinged evolutionism, which Ernst Haeckel considered false and very dangerous. The Jesuit biologist from Catalonia, Jaime Pujiula, continued Wasmann's work but adopted stances that were more radical than the Austrian entomologist's, like invoking the inescapable need for God's intervention in the transition from inert matter to life.

Keywords: spontaneous generation, origin of life, Ernst Haeckel, Charles Darwin, Catholic dogma.

At the beginning of the twentieth century, scientists of Christian tradition who were inclined to accept an evolutionary vision that did not oppose the existence of a deity used to distinguish between the God of primary causes and the emergence of species due to «secondary causes». A different response, often adopted by many Catholic theologians was to deny the scientific nature of the theory of evolution and to resort to teleological or finalist explanations of the evolutionary process. Despite all of this, the obstacles of the origin of life, and of humans, were always present. The origin of the latter would become a permanent and insurmountable boundary for Catholic theology and for the Roman authorities. How did the hierarchy treat the Catholic authors who publicly supported evolution? Mariano Artigas, Thomas F. Glick and Rafael A. Martínez studied the 1877-1902 period using six cases collected in the Archives of the Congregation for the Doctrine of the Faith (Artigas, Glick, \& Martínez, 2006): Raffaello Caverni, Dalmace Leroy, John A. Zahm, Geremia Bonomelli, John C. Hedley and St. George J. Mivart were six authors determined to harmonise evolution and Christianity and to provide some public resonance. The Vatican acted against them discreetly: despite the tension, the Vatican never officially condemned evolutionism. Artigas and his colleagues' interpretation is that the remaining shadow of Galileo's case - some documents related to the process were published at the end of the nineteenth century - and the public pre-eminence of contemporary science, counselled for caution and encouraged the Vatican to avoid conflict with natural science; in the end, evolutionism was confronted without any fervour or explicit disapproval.

We must stress that the conciliatory efforts between evolution and theology were not exclusively Catholic. Many authors, some of them Darwin's contemporaries, initiated this effort by moving away from strict Darwinism and outlining a finalist and theistic evolutionary perspective. To cite only a few, the stand-out authors in evolutionary biology at the time included the Anglicans Baden Powell, Alfred R. Wallace and Ronald A. Fisher, the Russian Orthodox Theodosius Dobzhansky and the Presbyterians Asa Gray, James Woodrow and Sewall Wright.

In any case, the authors studied by Artigas and his colleagues were only some of the many Catholics who tried to reconcile evolutionism and Catholic theology at the beginning of the twentieth century. In this article we expose the case of Erich Wasmann, a prominent 


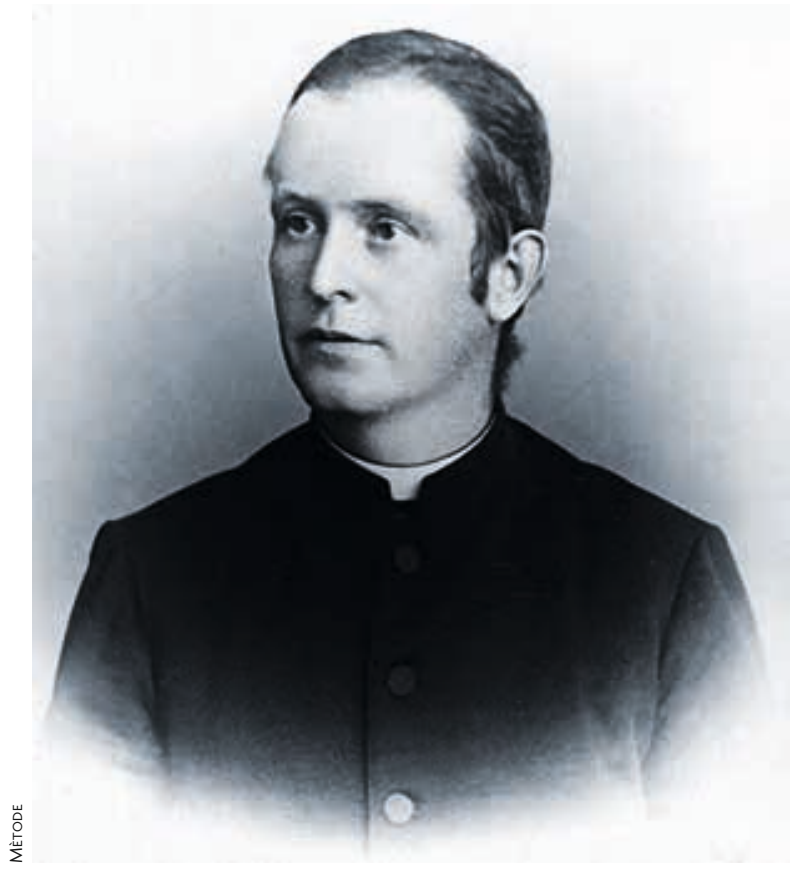

The Jesuit entomologist Erich Wasmann (1859-1931) came to the conclusion that evolutionary theory could explain his observations about myrmecophiles, so he adopted a form of Catholicism-tinged evolutionism, which Ernst Haeckel considered false and very dangerous.

entomologist and Jesuit whose research drove him to accept, with some caveats, the premises of the evolutionary process (Lustig, 2002; Richards, 2008). Wasmann, his work and influence on other Catholic authors have not yet been extensively studied. In fact, during his media debates with Ernst Haeckel, the Jesuit defended himself by denying that his theistic vision had not been officially sanctioned by the Vatican or the Society of Jesus (Richards, 2008). Here, we compare Wasmann's evolutionary notion - especially regarding the origin of life - with that of one of his most prominent followers, Jaime Pujiula, also a Jesuit.

\section{THE BATTLE BETWEEN VITALISM AND MATERIALISM}

Some historians saw that, at the beginning of the twentieth century, intellectual conditions were favourable for the emergence of a neovitalist approach as an alternative to materialist and mechanical philosophies from authors such as Hans Driesch (1867-
1941) in Germany and Henri Bergson (1859-1941) in France. It would be a reaction to the perplexity among scientists and philosophers regarding the relationship between inert matter and living beings: a dualistic concept that considers matter and life as two different categories and sees the transformation from one to the other as impossible (Fry, 2000). Neovitalism could also be seen as a philosophical response to the growing number of mechanistic scientists who considered life to be the result of the interaction between the chemical components of a cell. This was the central idea in Jacques Loeb's (1859-1924) research programme, which had a clear objective: producing artificial life. Some of the early followers of a synthetic approach to life, like the French scientist Stéphane Leduc (1853-1939) and the Mexican Alfonso L. Herrera (1868-1943), tried to better understand both current life and its origin on Earth (Peretó \& Català, 2012). Loeb, Leduc and Herrera's work, just as Haeckel's had, worried vitalist scientists with strong religious connections, especially European Catholics: Jaime Pujiula (1869-1958) in Spain, Agostino Gemelli (1878-1959) in Italy and Jean Maumus (1860-1930) in France were Catholic priests and scientists who authored scathing critiques of materialistic approaches to life. All of them had a religious background in common (Pius X's anti-modernism), as well as their anti-Haeckelian (anti-monistic) ${ }^{1}$ stance.

They declared themselves followers of a dualistic philosophy and acknowledged Pasteur's scientific rebuttal of spontaneous generation.

Another point in common among these neovitalist authors was the acceptance of Erich Wasmann's evolutionary views, albeit with the exception of his assumptions about the origin of life. Wasmann was born in Meran (South Tyrol) in 1859. In 1875, he became a Jesuit novitiate in Limburg (the Netherlands). He combined his education in scholastic philosophy and theology with a remarkable fondness for entomology, particularly for the study of beetles. His first studies reflect his criticism of Darwinism and give a sense of his appreciation of living beings having a purpose, inspired by the work of Aristotle

\footnotetext{
${ }^{1}$ Monism covers any theory defending the existence of a single primordial principle. In Haeckel's case, this principle was pure matter, and he followed a materialistic monism that excluded any possibility of immaterial entities.
} 
and Saint Thomas. His research would soon focus on myrmecophiles, especially on species of beetles that live symbiotically with ants. From this work he created an evolutionary interpretation which is reflected in a series of publications and in Die moderne Biologie und die Entwicklungstheorie, a treatise on evolutionary theory published in 1903, and whose third edition was translated into English (Wasmann, 1910). Wasmann's conciliatory theory was not strictly Darwinist, but rather, a hybrid of the ideas of Hugo de Vries and Hans Driesch (Richards, 2008). His confrontation with monism and with Haeckel also emerge in the 1907 Berlin lectures (Wasmann, 1912). Wasmann died in 1931 at the Ignatius College in Valkenburg (the Netherlands).

For Haeckel, the prestigious entomologist and Jesuit priest was an opponent: he saw Wasmann as the worst enemy of science (Lustig, 2002; Richards, 2008). One of Wasmann's books summarised his evolutionary thinking (Wasmann, 1910) and was considered by Haeckel «a masterpiece of Jesuitical confusion and sophistry» (Richards, 2008, p. 360). In fact, the book motivated him to give his last series of public lectures in Berlin. Haeckel proclaimed the incompatibility of the theory of evolution and any religious thinking inspired by scientific fact, as represented by Wasmann, who he deemed the most dangerous of the religious scientists:

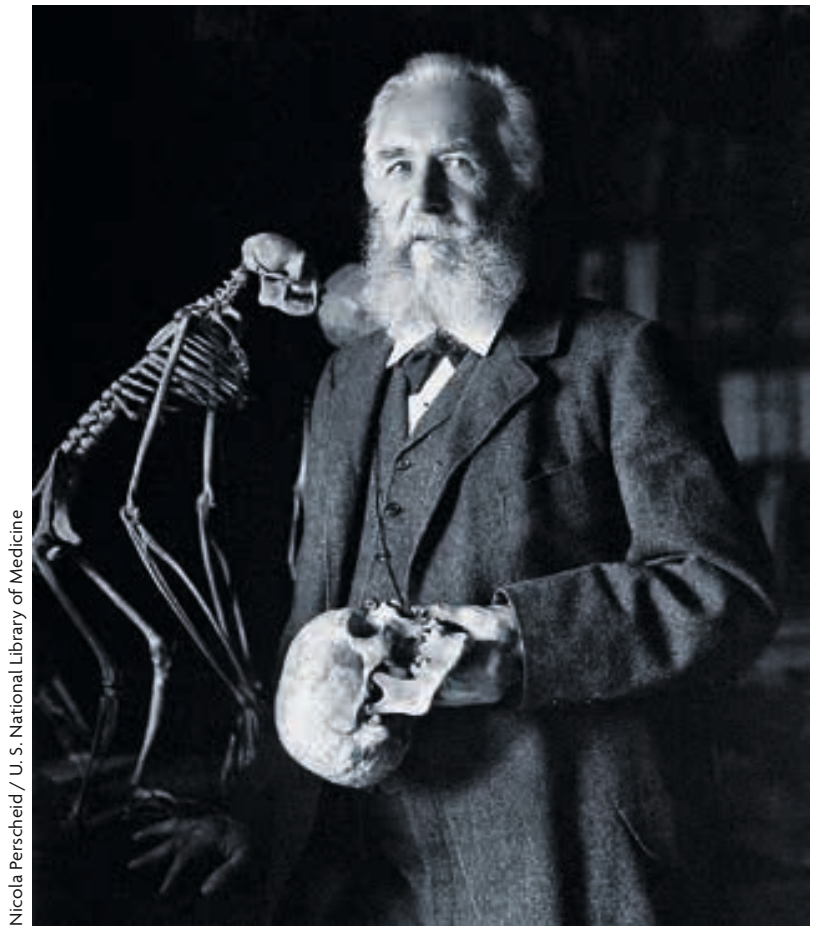

Haeckel's lectures in Berlin took three days in April 1905, were celebrated at the Sing-Akademie, and had a spectacular public impact. In them, Haeckel dealt with the confrontation between evolution and dogma, the evidence that supported human evolution within the branch of primates, and the controversy regarding the existence of an immortal soul.
[...] not only because that writer deals with the subject more ably and comprehensively than most of his colleagues, but because he is more competent to make a scientific defense of his views on account of his long studies of the ants and his general knowledge of biology.

(Haeckel, 1906, p. 171)

Haeckel's lectures in Berlin took three days in April 1905, were celebrated at the Sing-

Akademie, and had a spectacular public impact (Haeckel, 1906). In them, Haeckel dealt with the confrontation between evolution and dogma, the evidence that supported human evolution within the branch of primates and, finally, the controversy regarding the existence of an immortal soul. The book that compiles the conference talks contains a priceless postscript: «Evolution and Jesuitism». ${ }^{2}$

\footnotetext{
${ }^{2}$ The postscript can be found, among other archives, in:

https://archive.org/details/lastwordsonevolu00haecrich (pages 171-179).
}

Haeckel considered it a triumph that the main opponent of science, «the Church», tried to reconcile itself with evolution. Of all the (mostly frustrated) attempts at harmonisation, Haeckel emphasised the quality of Wasmann's efforts, despite the fact that he considered both doctrines, evolution and Christianity, to be absolutely opposed and irreconcilable.

Wasmann, on the other hand, could not be outdone and accepted an invitation to offer three lectures, also at Sing-Akademie in Berlin, and to participate in a public debate with scientists in a fourth session held at the Great Hall of the Zoological Garden. These events, celebrated in February 1907, were attended by thousands of people and attracted the attention of the media. They were later published as a book and translated into English (Wasmann, 1912). In the first lecture, he detailed the fundamental ideas of evolutionary theory; in the second, he differentiated between theistic and atheistic 
evolution - distinguishing between evolution and Darwinism - and in the third, he focused on human evolution. Regarding the origin of life, unlike Haeckel, who took a Darwinist stance, Wasmann considered the problem to be beyond evolutionary explanation. For him, it was a philosophical issue, not a scientific one (Wasmann, 1912). Using Pasteur as a scientific basis to support his ideas, Wasmann categorically rejected spontaneous generation and invoked a «superior cause» for the origin of the first organisms. However, Wasmann considered that, for his «Christian theory of the universe», the act of the creation of life was conditioned by the advancement of science: «Should science be in a position to prove that spontaneous generation is actually possible, and that living beings could proceed spontaneously from inorganic matter, theism should at once surrender this postulate» (Wasmann, 1912, p. 29).

\section{EVOLUTION ACCORDING TO PUJIULA}

Jaime Pujiula Dilmé was born in Besalú (Garrotxa, Spain) in 1869 . His first contact with natural history was during a stay in Germany between 1890 and 1893. In 1895, he was transferred to the Saint Joseph School in Valencia, where he would teach sciences from 1899 to 1901 . In 1906, Pujiula became a priest and extended his studies at the University of Innsbruck, the Trieste Zoological Station and the Institute of Embryology in Vienna. He received a $\mathrm{PhD}$ from the University of Berlin and, in 1908, he was asked to create the Ebro Biological Laboratory in Roquetes (at the same time the Ebro Chemical Laboratory was founded by the scientist from Alcoi, Eduard Vitoria), which in 1916 became the Sarrià Biological Laboratory in Barcelona. Until he died in 1958, Pujiula taught, researched and communicated biological news - focusing on evolutionism - and directed the Laboratory. Even though his body of published work was vast and diverse, he made remarkable contributions to cytology, histology and embryology (Durfort, 1995).

A significant aspect of Jaime Pujiula's personality was his polemic character, expressed and reflected in many publications, some of them derived from public speeches. This was the case with the lectures he delivered in Barcelona (Pujiula, 1910) and Valencia
(Pujiula, 1915), in which he talked about the theory of evolution and some specific problems that concerned him from his Catholic perspective. Between 18 and 23 April 1910, Pujiula gave six lectures to the Immaculate Mary and Saint Lluís Gonzaga congregation in Barcelona. These lectures were motivated by his interest in «preventing [young students, mainly scholars] from approaching certain ideas and theories which, despite being false, wrong or suspicious, tend to be considered as official by university chairs» (Pujiula, 1910, p. 13), and are disseminated by the «plague of materialists that infests the current scientific world» (Pujiula, 1910, p. 15). According to Pujiula, there is confusion in science, particularly in biology, because it tries to explain and understand life in purely materialistic terms and confuses essential concepts like the ones evoked by the term evolution. Indeed, Pujiula distinguished between «ontogenetic» evolution, «true, not theoretical, but real», and «phylogenetic» evolution, which he considered «speculative» (Pujiula, 1910, p. 17). Pujiula delimited Darwin's contributions as well, insisting on the existence of many predecessors also with evolutionary ideas, among which he cited Lamarck and Geoffroy Saint-Hilaire, and stressed the validity of the evolutionary debate (or, to him, speculation) referring to Hugo de Vries's mutationism, to neo-Lamarckism and to neo-Darwinism, as all being involved in an attempt to «untie the Gordian Knot and to prove and explain, if they could, the transformation of species» (Pujiula, 1910, p. 23).

Pujiula pointed out, as many other authors have also done, that Darwin refused to explain the origin of life in his work, instead invoking divine intervention; for this reason he often quoted the last paragraph of the sixth edition of On the origin of species (the version Pujiula used). It is common knowledge that Darwin added the mention of the Creator in the second edition of his book but that he soon recognised this concession to readers to have been a mistake (Peretó, Bada, \& Lazcano, 2009). Be it as it may, for Pujiula it was proof that:

The theory of descent or evolution, as proposed in this work by Darwin, is not an atheistic theory, of course. Besides, it recognises two limits or frontiers that Darwin did not want to trespass: the origin of life on the one hand and the origin of man on the other.

(Pujiula, 1910, p. 25) 


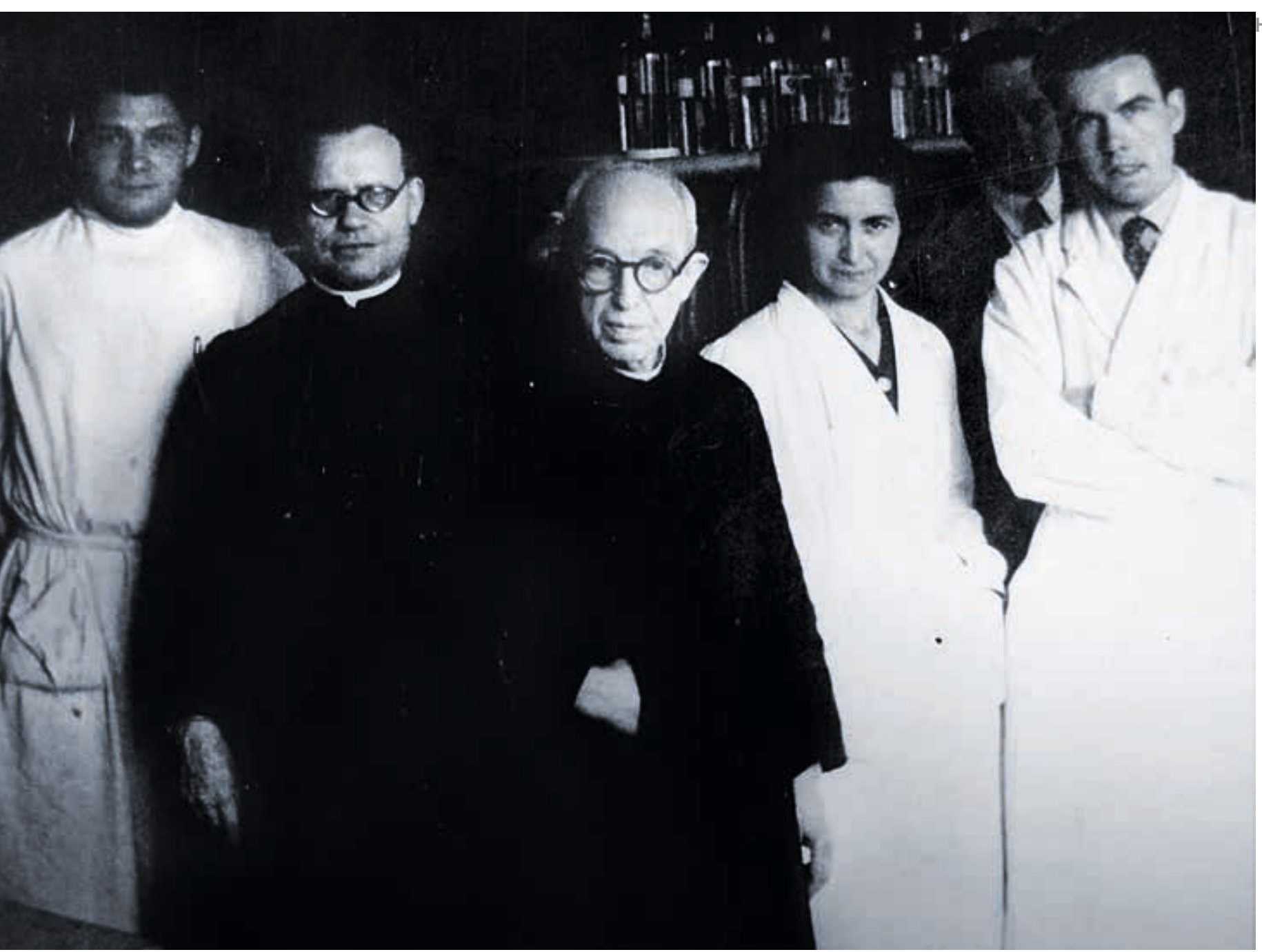

According to Jaime Pujiula (1869-1958), there is confusion in science, particularly in biology, because it tries to explain and understand life in purely materialistic terms and confuses essential concepts like the ones evoked by the term evolution. In the picture, Pujiula at the centre, stands next to a colleague and some students in 1951.

Pujiula's programme was clear: leaving aside the origin of life, we can observe the evolution of plants and animals; this excludes humans, whose existence must be explained by more than science - for them we also have to take metaphysical considerations into account. This was a programme that directly confronted Haeckel's monism, the Society of Jesus' quintessential antagonist (Richards, 2008). Thus, Haeckel's monist evolution is considered «true atheism» with the ultimate objective of ending Christianity, «a series of errors and nonsense against faith, against philosophy and against science» (Pujiula, 1910, p. 28), thus explaining why Pujiula would devote his second lecture to a «Refutation of the monist system and evolution».

In this second lecture, Pujiula uses all his dialectical artillery against Haeckel and monism and, particularly, against the proposal to accept some type of spontaneous generation as the origin of life. He invoked tradition and scientific evidence (Redi, Pasteur, Tyndall), attacked the scientists who tried to reproduce the emergence of biological structures in the laboratory (Leduc, Delgado Palacios) and raged against materialists in general. Monism, he concluded, «is a false system [...] against reason, it admits the eternity of matter and energy [...] violates facts and laws when it defends spontaneous generation [...], facts banish it from the field of science and philosophy» (Pujiula, 1910, p. 50). In the third lecture, Pujiula established the impossibility of strictly material explanations for the transition from «brute or mineral matter» to «vegetative life» or the step from animal «sensitivity» to the «intelligence or mentality» of the «king of Creation» (Pujiula, 1910, p. 71). Pujiula devoted his fourth lecture solely to rejecting the theory of descent as applied to human beings.

In contrast, the fifth lecture focused on application of the evolutionary vision, with the appropriate restrictions: «already free [...] from demonstrably wrong aspects, we can calmly examine the theory within its limits, that is, within the strictly organic sphere, on the one hand constituted by plants and 


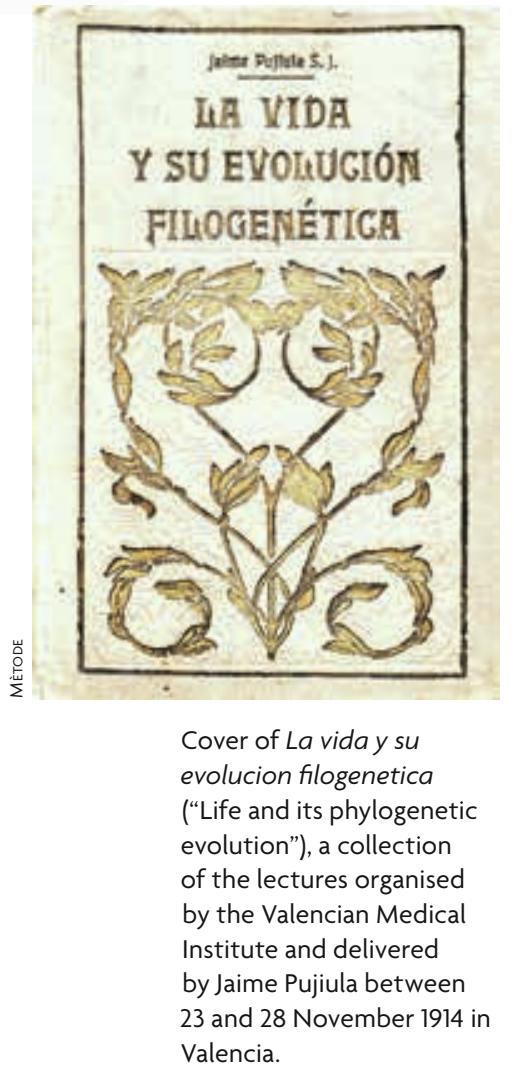

animals, always excluding human beings, and on the other, assuming the existence of life or of the first organisms on our planet, to be the result of God's intervention» (Pujiula, 1910, p. 95). Therefore, evolution would be merely a hypothesis and, should we have to choose an explanation, we would choose to use a Lamarckian one, closer in its finalism to the teleological principle to which he enthusiastically adhered and used in several of his publications (Català, 2013). The sixth lecture, which he used for recapitulation and conclusions, reflected Pujiula's fear that evolutionary ideas reinforced the process of secularisation which was ongoing at the time. All in all, he considered the whole process to be another episode in the Church's fight against its enemies - who, of course, he believed would eventually be defeated.

Between 23 and 28 November 1914, Pujiula was invited by the Valencian Medical Institute to give six lectures at the Main Hall of the University of Valencia, the same place where, a little over five years before, the only act of academic celebration in Spain for the centenary of Darwin's birth had been held. The lectures were originally published in 1915 (Pujiula, 1915) but here we cite the revised second edition, published in 1925. These lectures show that the essence of Pujiula's perspective regarding evolution, made public in Barcelona in 1910, still prevailed. The Jesuit had kept in contact with some conservative doctors who, through the Valencian Medical Institute, organised the Biology Week titled «Life and its phylogenetic evolution». Despite the themes being organised differently to his previous lectures, once again, finalism, dualism and vitalism were the thematic threads of Pujiula's speeches, as was his antagonistic relationship with
Haeckel, monism, and anyone who tried to synthesise life, such as Leduc and Herrera. He also expressed his disdain for Darwin and his theory, in contrast to his sympathy for Lamarck. Pujiula reviewed, throughout the six lectures, the characteristic features of life, the attempts to synthesise it, the teleological character of living beings, organicism and neovitalism, the excesses of «panpsychism» and the theory of descent and its application to the emergence of humans.

In the Valencia lectures, Pujiula also added several references to local situation, such as his invective against Eduard Boscà, retired professor from the University of Valencia and director of the Palaeontological Museum. Boscà had been involved in the controversy over whether the human species was as old as the Tertiary age; he also supported the opinion of the Argentinian palaeontologist Florentino Ameghino concerning the case of some human remains deposited in the museum, a controversy Pujiula critiqued harshly at the end of his last lecture (Català, 2013). Pujiula used it to disassemble Boscà's anatomical arguments regarding the skeleton in the Rodrigo Botet collection, originally from Samborombón (Argentina), and insisted that Ameghino and his ideas were completely discredited.

\section{A VARIETY OF EVOLUTIONARY VIEWS}

For very different reasons, Darwin and Wasmann excluded the origin of life from the general evolutionary picture. Darwin argued privately that the emergence of life was a chemical process. He did so, for instance, in his famous letter to Hooker in 1871 , in which he referred to the «warm little pond», as well as in other unpublished texts. But he also recognised that the problem was extraordinarily complicated and was beyond the reach of experimentation at the time (Peretó, Bada, \& Lazcano, 2009). Conversely, Wasmann's stance was philosophical and compelled by Pasteurian tradition against spontaneous generation. Let us remember that Wasmann's «theistic theory of life», which assumed there had been divine intervention in the origin of the first organisms, admitted the possibility of a future demonstration of spontaneous generation and thus of the subsequent withdrawal of the claim that «we see acceptance of a personal Creator as a true scientific postulate» (Wasmann, 1910, p. 205). In fact, as we have already stated, Wasmann recognised, in the second Berlin lecture 


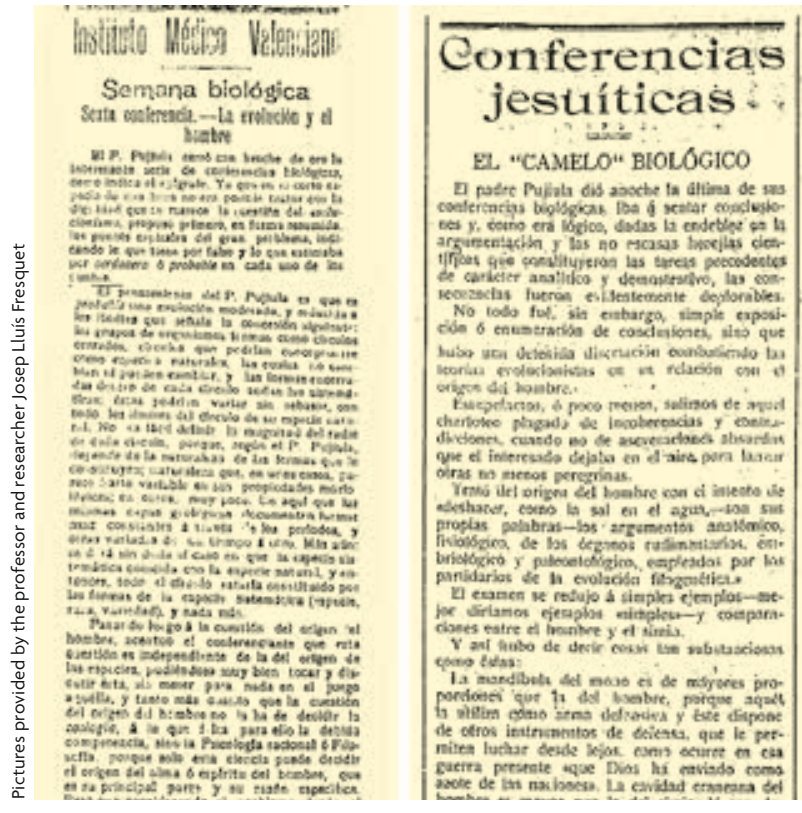

Jaime Pujiula's lectures in Valencia sparked controversy which was reflected in the press at the time. The two pictures show the dissimilar coverage of the lecture series in the newspapers Las Provincias (with an article titled «Biology week. Sixth conference - Evolution and man", on the left), and El Pueblo (titled "Jesuitic lectures: The biological "hoax"”, on the right).

and during public debate, the conditional nature of this postulate (Wasmann, 1912).

Pujiula knew Wasmann's work very well, but we do not know whether they ever met in person during Pujiula's stays in Germany and Austria. He reviewed Wasmann's book on the theistic theory of evolution in the journal Razón y Fe (Pujiula, 1905), and in all his work, including the Barcelona and Valencia lectures, the Catalan Jesuit saw Wasmann as his author of reference. While Pujiula faithfully followed the idea of divine intervention in the origin of human beings - the official line of thought in the Catholic sphere - we have never found any trace in his work of Wasmann's conciliatory stance towards the possibility of a strictly natural origin of life. Thus, Pujiula's theistic dogmatism and orthodoxy were stricter than Wasmann's stance, although the extent to which Wasmann's opinion resonated with Catholic scientists remains to be studied.

In conclusion, Wasmann accepted the theory of evolution as a framework to explain his observations as a myrmecologist who was explicitly affiliated to Driesch's neovitalism and with an oddly sceptical ideological stance regarding the origin of life; this contrasted with the opinion of some of those following on from his work, such as Pujiula, and even more clearly so, with the very dogmatic versions of current creationism (Peretó, 2011). Some research has already looked at the reaction of the Catholic hierarchy to the acceptance of evolutionary ideas by priests and scientists, but more work is still needed. The cases that have been studied so far do not even come close to exhausting the wide variety of responses from different sections of the Catholic Church to the challenge posed by Darwin and his theories. In fact, such variety perfectly exhibits the debate and somewhat opposing opinions in the inner-circle of the institution itself, which are far from showing dogmatic or ideological unanimity.

\section{REFERENCES}

Artigas, M., Glick, T. F., \& Martínez, R. A. (2006). Negotiating Darwin: The Vatican confronts evolution, 1877-1902. Baltimore: Johns Hopkins University Press.

Català, J. I. (2013). Los jesuitas españoles ante el evolucionismo durante el período restauracionista (1875-1922). In R. Ruiz, M. A. Puig-Samper, \& G Zamudio (Eds.), Darwinismo, biología y sociedad (pp. 211-233). Mexico DF: UNAM; Ediciones Doce Calles.

Durfort, M. (1995). Jaume Pujiula i Dilmé, S. I. (Besalú, Garrotxa, 1869-Barcelona, 1958). La morfologia microscòpica. In J. M. Camarasa, \& A. Roca (Eds.), Ciència i tècnica als Països Catalans: Una aproximació biogràfica (pp. 827-858). Barcelona: Fundació Catalana per la Recerca.

Fry, I. (2000). The emergence of life on Earth. A historical and scientific overview. New Brunswick: Rutgers University Press.

Haeckel, E. (1906). Last words on evolution. New York: Peter Eckler.

Lustig, A. J. (2002). Erich Wasmann, Ernst Haeckel, and the limits of science. Theory in Biosciences, 121, 252-259. doi: 10.1007/s12064-002-0 013-8

Peretó, J. (2011). Book review. Creating life in the lab: How new discoveries in synthetic biology make a case for the creator. Reports of the National Center for Scientific Education, 31(6), 8.1-8.3.

Peretó, J., Bada, J. L., \& Lazcano, A. (2009). Charles Darwin and the origin of life. Origins of life and evolution of biospheres, 39, 395-406. doi: 10.1007/s11084-009-9172-7

Peretó, J., \& Català, J. (2012). Darwinism and the origin of life. Evolution: Education and Outreach, 5, 337-341. doi: 10.1007/s12052-012-0442-x

Pujiula, J. (1905). La moderna biología y la teoría de la evolución. Razón y Fe, $11,496-508 ; 12,59-69$.

Pujiula, J. (1910). Conferencias biológicas. Estudios críticos sobre la teoría de la evolución. Barcelona: Tipografía Católica Casals.

Pujiula, J. (1915). Conferencias sobre la vida y su evolución filogenética esta última particularmente con relación al hombre dadas del 23 al 28 de noviembre 1914 en el paraninfo de la Universidad de Valencia a petición del Instituto Médico Valenciano. Barcelona: Tipografía Católica Casals.

Richards, R. J. (2008). The tragic sense of life. Ernst Haeckel and the struggle over evolutionary thought. Chicago: Chicago University Press.

Wasmann, E. (1910). Modern biology and the theory of evolution. London: Kegan Paul, Trench, Trübner \& Co.

Wasmann, E. (1912). The Berlin discussion of the problem of evolution. Full report of the lectures given in February 1907, and of the evening discussion. London: Kegan Paul, Trench, Trübner \& Co.

Juli Peretó. Tenured university professor of Biochemistry and Molecular Biology and researcher at the Cavanilles Institute of Biodiversity and Evolutionary Biology at the University of Valencia (Spain). His publications include work on metabolic evolution, symbiosis, the problem of the definition of life, the history of ideas on the natural origin, and the artificial synthesis of life. In 2014, he became a Fellow of the ISSOL (International Society for the Study of the Origin of Life).

Jesús I. Català. Tenure-track History of Science lecturer at the CEU Cardenal Herrera University (Valencia, Spain). He studies the history of biology and natural history in Spain and Portugal during the nineteenth and twentieth centuries, their institutional development and the ideological aspects associated with them. 